\title{
The effects of lactic acid bacteria and mannan oligosaccharide, with or without fumaric acid, on chicken performance, slaughter yield and digestive tract microflora
}

\author{
F. Brzóska ${ }^{1,4}$, S. Buluchevskij ${ }^{2}$, K. Stecka ${ }^{3}$ and B. Śliwiński ${ }^{1}$ \\ ${ }^{1}$ National Research Institute of Animal Production, \\ Department of Animal Nutrition and Feed Science \\ 32-083 Balice, Poland \\ ${ }^{2}$ Institute of Feed Science and Animal Nutrition, Moscow, Russia \\ ${ }^{3}$ Institute of Agriculture and Biotechnology \\ Rakowiecka 36, Warszawa, Poland
}

(Received 2 February 2006; revised version 22 January 2007; accepted 2 May 2007)

\begin{abstract}
In an experiment performed on 600 ROSS broilers the effect of dietary lactic acid bacteria (LAB), mannan oligosaccharide (MOS) without (LAB, MOS) or with fumaric acid (LAB, MOS, FUA) in comparison with antibiotic-supplemented birds (ANT) on performance, mortality, carcass yield, and microflora spectrum of the digestive tract was studied. The body weight of birds at 42 days was 2.2, 2.5, 2.4 and $2.4 \mathrm{~kg}$, in the CON, ANT, LAB + MOS and LAB + MOS + FUA groups, respectively $(\mathrm{P} \leq 0.01)$. No significant differences between the body weights in the antibioticsupplemented (ANT) and experimental groups were found. Bird mortality in the CON, ANT, $\mathrm{LAB}+\mathrm{MOS}$ and $\mathrm{LAB}+\mathrm{MOS}+\mathrm{FUA}$ groups was $2.7,0.0,0.7$ and $0.7 \%$, respectively. Compared with the control group, use of the antibiotic or other additives increased feed intake by $0.49 \mathrm{~kg} / \mathrm{bird}$, on average. Dressing percentage averaged $73.5 \%$ and was significantly higher in the experimental groups $(\mathrm{P} \leq 0.05)$. The weight of cold carcasses averaged $1.8 \mathrm{~kg}$ and was significantly lower in group $\mathrm{CON}(\mathrm{P} \leq 0.01)$. The $\mathrm{pH}$ of the digestive tract did not differ among groups. LAB and MOS with or without FA increased significantly $(\mathrm{P} \leq 0.05)$ the counts of Streptococcus $(\mathrm{P} \leq 0.01)$ and Lactobacillus in the ileal digesta. The Streptococcus and Escherichia coli counts in the caecal digesta decreased significantly $(\mathrm{P} \leq 0.01)$. No Salmonella, Shigella and Campylobacter were found in the small intestine or caecum of any of the groups.
\end{abstract}

KEY WORDS: broiler chicken, lactic acid bacteria, mannan oligosaccharide, fumaric acid, performance, slaughter yield, digestive tract microbiota

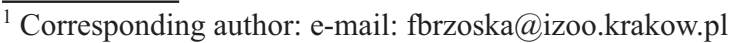




\section{INTRODUCTION}

Probiotic lactic acid bacteria and oligosaccharides have shown positive effects on the digestive tract of birds (Cavazzoni et al., 1998; Brzóska et al., 1999; Audisio et al., 2000; Spring et al., 2000). Lactic acid bacteria (LAB) living symbiotically in the digestive tract of birds were found to enhance the immunity of animals to pathogenic bacteria (Zulkifli et al., 2000). LAB have adhesive properties and can colonize different parts of the avian digestive tract (Jin et al., 1996). By metabolizing glucose $\mathrm{LAB}$ produce lactic acid, which acidifies the digestive milieu, and bacteriocines that inhibit pathogenic bacteria such as Salmonella, Escherichia coli, Campylobacter and Listeria (Joerger, 2003; Patterson and Burkholder, 2003). Beneficial effects of probiotic bacteria on reducing mortality and increasing the body weight of broilers have been reported (Cavazzoni et al., 1998; Brzóska et al., 1999). Enteroccocus faecium were shown to inhibit the mortality of chickens infected with Salmonella pullorum (Audisio et al., 2000). Mannan oligosaccharide (MOS) is a product derived from yeast cell walls, and is not digested by animals. The optimum amount of MOS in bird diets is considered to be $10-20 \mathrm{~g} / \mathrm{kg}$ diet (Savage and Zakrzewska, 1996). Low-molecular organic acids, such as fumaric or formic acids, also improve the microbiological quality of feeds and reduce the buffering capacity of digesta and the levels of some microorganisms in the feed and caecum of birds (Van der Wielen et al., 2000; Chaveerach et al., 2004).

The aim of this study was to evaluate if LAB and MOS given together, with or without fumaric acid (FUA), would have a positive effect on the performance of broilers and reduce undesired intestinal microflora counts in chickens in comparison with birds receiving feed without additives or with an antibiotic.

\section{MATERIAL AND METHODS}

A total of 600 ROSS 1-day-old unsexed broiler chickens were randomly allotted to 4 groups, two replications of 75 birds per group. Chickens were kept in cages with sawdust floors, stocking density was $13.2 \mathrm{birds} / \mathrm{m}^{2}$. Broilers were fed maize, wheat and soyabean meal diets to 42 days of age (Table 1). The control group (CON) receive the diet without additives, the ANT group received the diet with the antibiotic Flavomycin $(5 \mathrm{mg} / \mathrm{kg}$ feed). The third group (MOS) received oligosaccharide $(1 \mathrm{~g} / \mathrm{kg}$ feed) and lactic acid bacteria (LAB). The fourth group was given MOS (1 g/kg feed), lactic acid bacteria (LAB) and fumaric acid (FUA) $(9.7 \mathrm{~g} / \mathrm{kg})$. The LAB used in the study contained the following strains of bacteria: $L$. paracasei KKP 824, L. rhamnosus KKP 825 and L. rhamnosus

KKP $826(6.7 \times 108 \mathrm{cfu} / \mathrm{g})$ at a 1:2:2 ratio (Institute of Agricultural and Food Biotechnology, Warsaw). The bacteria were used at rate of 3 million bacterial 
Table 1. Feed composition and nutritive value, $\mathrm{g} \cdot \mathrm{kg}^{-1}$

\begin{tabular}{lcc}
\hline \multirow{2}{*}{ Item } & \multicolumn{2}{c}{ Diet } \\
\cline { 2 - 3 } & starter, 1-21 days & grower, 22-42 days \\
\hline Ingredients & 380.0 & 300.0 \\
maize & 265.0 & 301.0 \\
wheat & 281.0 & 325.0 \\
soyabean meal & 40.0 & 40.0 \\
rape seed oil & 17.0 & 17.0 \\
dicalcium phosphate & 6.0 & 6.0 \\
limestone & 3.5 & 3.5 \\
NaCl & 1.1 & 1.1 \\
L-lysine HCl (78\%) & 1.4 & 1.4 \\
DL-methionine (99\%) & 5.0 & 5.0 \\
vitamin-mineral premix ${ }^{1}$ & & \\
Nutrients in 1 kg of dry matter & 209.9 & 194.7 \\
crude protein, g & 11.9 & 10.6 \\
lysine, g & 4.6 & 4.4 \\
methionine + cystine, g & 8.6 & 8.5 \\
calcium, g & 4.0 & 4.0 \\
phosphorus, g & 12.39 & 12.61 \\
metabolizable energy, MJ & & \\
\hline
\end{tabular}

${ }^{1}$ supplied to $1 \mathrm{~kg}$ of starter diet, IU: vit. A 13 5000; vit. $\mathrm{D}_{3} 3600$; mg: vit. E 45; vit. $\mathrm{B}_{1} 3.25$; vit. $\mathrm{B}_{2} 7.5$; vit. $\mathrm{B}_{6} 5$; vit. $\mathrm{B}_{12} 0.0325$; vit. $\mathrm{K}_{3}$ 3; biotin 0.15 ; nicotinic acid 45; Ca-pantothenate 15 ; folic acid 1.5; choline chloride 100; Mn 100; Cu 1.75; Fe 76.5; Se 0.275; I 1; Zn 75; Co 0.4; Endox (antioxidant) 125; g: Sincox (coccidiostat) 1; Ca 0.679 supplied to $1 \mathrm{~kg}$ of grower diet, IU: vit. A 12 000; vit. $\mathrm{D}_{3}$ 3 250; mg: vit. E 40; vit. $\mathrm{B}_{1} 2$; vit. $\mathrm{B}_{2}$ 7.25; vit. $\mathrm{B}_{6} 4.25$; vit. $\mathrm{B}_{12} 0.03$; vit. $\mathrm{K}_{3} 2.25$; biotin 0.1 ; nicotinic acid 40; Ca-pantothenate 12; folic acid 1.0; choline chloride 450; $\mathrm{Mn} \mathrm{100;} \mathrm{Cu}$ 1.75; Fe 76.5; Se 0.275; I 1; Zn 75; Co 0.4; Endox (antioxidant) 125; g: Sincox (coccidiostat) 1; Ca 0.79

cells/bird/day. LAB were added to drinking water for the first two days starting directly after the chickens were introduced into the boxes. The procedure was repeated on days 22-23 of rearing. The MOS (BIOMOS) feed additive was from Alltech-Polska Co., FUA originated from ORFFA-Polska Comp.

Chickens were fed ad libitum with starter and grower diets (Table 1). Water was supplied via trough-type waterers. Chickens were weighed individually on days 21 and 42 of life, after $12 \mathrm{~h}$ fasting. During the experiment mortality was recorded, feed intake was measured per pen, average feed intake per bird was calculated.

Intestinal microflora was examined in five 35-day-old randomly chosen birds from each pen, ten birds from group. Digesta from the small intestine, caecum and cloaca was collected immediately after slaughter. Digesta was evacuated, mixed and $\mathrm{pH}$ was measured. Samples for microflora analyses were taken into sterile tubes. The microbiological analyses were performed in accordance with the procedure recommended by the National Institute of Hygiene (Poland) (unpublished). Samples 
( $1 \mathrm{~g}$ fresh mass) were mixed with $5 \mathrm{ml} 0.85 \%$ physiological saline solution and spread with a calibrated loop on to MacConkey (differentiating plate for gram-negative rods, including Enterobacteriaceae), SS (selective plate for Salmonella and Shigella rods), and blood agar plates (preventing the growth of gram-positive and gramnegative microorganisms and some fungi). The plates were then incubated for $24 \mathrm{~h}$ at $37^{\circ} \mathrm{C}$ and the number and types of colonies that had grown were evaluated. Tests for Salmonella and Shigella were performed on a liquid with acid sodium selenite and a latex assay was performed after 18-24 h of incubation using a BIOMEX kit. Campylobacter tests were performed by incubation under a nitrogen atmosphere on selective agar plates (Oxoid) and placed into an anaerostat jar with a kit generating a microaerophilic atmosphere. The cultures were incubated for $48 \mathrm{~h}$ at $37^{\circ} \mathrm{C}$. The grown colonies were evaluated on the basis of morphology, direct and Gram-stained slides, and preliminary tests differentiating the production of catalase and oxidase. Colonies were identified on the basis of the National Institute of Hygiene (Poland) methodology (unpublished). Clostridium tests were performed by incubation under a nitrogen atmosphere on selective agar plates (Oxoid) and placed into an anaerostat jar with a kit generating an anaerobic atmosphere. The cultures were incubated for $48 \mathrm{~h}$ at $37^{\circ} \mathrm{C}$. The grown colonies were evaluated on the basis of morphology and direct and Gram-stained slides. Suspicious colonies were identified using the ATB Expression system (bioMerieux).

On day 43 of age, 10 birds ( 5 males and 5 females) were randomly chosen from each group and slaughtered. Hot carcasses, gizzard, liver, breast and leg muscles were weighed postmortem and the parts were stored in a cold room at $5^{\circ} \mathrm{C}$ for 24 $\mathrm{h}$. The $\mathrm{pH}$ of breast muscle (M. pectoralis maior and minor) was measured 1 and $24 \mathrm{~h}$ postmortem. On the following day, carcasses were dissected according to the procedure given by Zgłobica and Różycka (1972), and the weights of cold carcass, breast muscle and leg muscle were determined. Samples of the right breast muscle were minced and frozen prior to subsequent chemical analysis. After thawing, the samples were analysed for dry matter, crude protein, crude fat and crude ash content (AOAC, 1990).

The results were calculated statistically with one-way analysis of variance and the new multiple Duncan's range test (SAS Institute, 1989).

\section{RESULTS}

Feeding the chickens LAB, MOS and FUA resulted in a final body weight that was $1.3 \%$ lower than the body weight of ANT-supplemented chickens, but $10.3 \%$ higher than that of the unsupplemented control chickens $(\mathrm{P}<0.01)$. The difference between the control and experimental groups was highly significant $(\mathrm{P}<0.01)$, while the differences between the ANT group and the experimental 
groups were not significant (Table 2). Mortality in the experimental groups was lower than in the control. The use of the antibiotic and LAB with the other

Table 2. Performance of broiler chickens

\begin{tabular}{llllll}
\hline & \multicolumn{5}{c}{ Dietary treatment } \\
\cline { 2 - 5 } Item & control & antibiotics & $\begin{array}{c}\text { LAB } \\
\text { MOS }\end{array}$ & $\begin{array}{c}\text { LAB } \\
\text { MOS } \\
\text { FUA }\end{array}$ & SD \\
\hline Body weight, $\mathrm{kg}$ & & & & & \\
$\quad 21$ day & $0.587^{\mathrm{aA}}$ & $0.703^{\mathrm{bB}}$ & $0.732^{\mathrm{bB}}$ & $0.720^{\mathrm{bB}}$ & 0.120 \\
$\quad 42$ day & $2.198^{\mathrm{aA}}$ & $2.456^{\mathrm{bB}}$ & $2.398^{\mathrm{bB}}$ & $2.450^{\mathrm{bB}}$ & 0.333 \\
Mortality, \% & 2.7 & 0.0 & 0.7 & 0.7 & 1.9 \\
Feed consumption, $\mathrm{kg} / 42$ days & 3.71 & 4.34 & 4.16 & 4.10 & 0.56 \\
Feed conversion ratio, $\mathrm{kg} / \mathrm{kg} \mathrm{BWG}$ & 1.77 & 1.76 & 1.77 & 1.69 & 0.23 \\
\hline
\end{tabular}

LAB - lactic acid bacteria; MOS - mannan oligosaccharide; FUA - fumaric acid

a,b,A,B values in the same rows with different letters differ significantly at $(\mathrm{P}<0.05)$ and at $(\mathrm{P}<0.01)$

additives increased feed intake and decreased feed conversion compared with the control group, but the differences were not significant.

LAB together with the other additives in both experimental groups significantly increased the weight of carcasses and the dressing percentage $(\mathrm{P}<0.01)$. Giving the chickens a diet containing antibiotic or LAB and the other feed additives significantly reduced the proportion of liver in body weight $(\mathrm{P}<0.01$; Table 3$)$.

Table 3. Slaughter yield, dressing percentage, breast and leg muscles weight

\begin{tabular}{lccccc}
\hline & \multicolumn{5}{c}{ Dietary treatment } \\
\cline { 2 - 5 } Item & control & antibiotics & $\begin{array}{c}\text { LAB } \\
\text { MOS }\end{array}$ & $\begin{array}{c}\text { LAB } \\
\text { MOS }\end{array}$ & SD \\
& & & & FUA & \\
\hline Live body weight (LBW), kg & $2.236^{\mathrm{aA}}$ & $2.450^{\mathrm{bBC}}$ & $2.408^{\mathrm{bB}}$ & $2.489^{\mathrm{cB}}$ & 0.191 \\
Carcass weight, $\mathrm{kg}$ & $1.622^{\mathrm{aA}}$ & $1.792^{\mathrm{bB}}$ & $1.844^{\mathrm{bB}}$ & $1.844^{\mathrm{bB}}$ & 0.197 \\
Dressing percentage, \% & $72.54^{\mathrm{a}}$ & $73.14^{\mathrm{a}}$ & $74.09^{\mathrm{b}}$ & $74.09^{\mathrm{b}}$ & 1.47 \\
\% of LBW: breast muscles & 24.64 & 24.68 & 24.33 & 24.33 & 1.20 \\
$\quad$ leg muscle & 22.17 & 21.73 & 21.70 & 21.70 & 1.15 \\
$\quad$ gizzard & 1.34 & 1.38 & 1.47 & 1.47 & 0.22 \\
liver & $2.54^{\mathrm{b}}$ & $2.58^{\mathrm{b}}$ & $2.09^{\mathrm{a}}$ & $2.09^{\mathrm{a}}$ & 0.33 \\
$\quad$ abdominal fat & $2.03^{\mathrm{aA}}$ & $2.53^{\mathrm{bB}}$ & $2.54^{\mathrm{bB}}$ & $2.54^{\mathrm{bB}}$ & 0.29 \\
\hline
\end{tabular}

a,b,c,A,B,C values in the same rows with different letters differ significantly at $(\mathrm{P}<0.05)$ and at $(\mathrm{P}<0.01)$ abbreviations see Table 2

The experimental groups were characterized by significantly higher fatness $(\mathrm{P}<0.01)$. Significant differences were in $\mathrm{pH} 24 \mathrm{~h}$ postmortem of ANT chickens compared with controls $(\mathrm{P}<0.01)$. There were no significant differences in the dry 
matter, protein, fat or ash contents of breast muscle among the birds of different groups (Table 4 ).

Table 4. Chemical composition (\% DM) and $\mathrm{pH}$ of breast meat

\begin{tabular}{lccccc}
\hline & \multicolumn{5}{c}{ Dietary treatment } \\
\cline { 2 - 5 } Item & control & antibiotics & $\begin{array}{c}\text { LAB } \\
\text { MOS }\end{array}$ & $\begin{array}{c}\text { LAB } \\
\text { MOS } \\
\text { FUA }\end{array}$ & SD \\
\hline Dry matter, \% & 25.1 & 25.5 & 25.4 & 25.3 & 0.50 \\
Crude protein, \% DM & 23.6 & 24.0 & 23.9 & 23.8 & 0.04 \\
Crude fat, \% DM & 0.83 & 0.94 & 0.95 & 0.95 & 0.50 \\
Crude ash, \% DM & 1.18 & 1.23 & 1.19 & 1.19 & 0.39 \\
pH, 1 h & 6.12 & 5.92 & 5.96 & 6.01 & 0.17 \\
pH, 24 h & $6.06^{\text {bB }}$ & $5.89^{\text {aA }}$ & $5.96^{\text {abAB }}$ & $5.97^{\text {abAB }}$ & 0.04 \\
\hline
\end{tabular}

a,b,A,B values in the same rows with different letters differ significantly at $(\mathrm{P}<0.05)$ and at $(\mathrm{P}<0.01)$ abbreviations see Table 2

The differences in the $\mathrm{pH}$ of the small intestine, caecum and cloaca digesta, between the groups of birds were not statistically significant (Table 5).

Table 5. $\mathrm{pH}$ of digesta

\begin{tabular}{lccccc}
\hline & \multicolumn{5}{c}{ Dietary treatment } \\
\cline { 2 - 5 } Part of intestinal tract & control & antibiotics & $\begin{array}{c}\text { LAB } \\
\text { MOS }\end{array}$ & $\begin{array}{c}\text { LAB } \\
\text { MOS } \\
\text { FUA }\end{array}$ & SD \\
\hline Crop & 4.68 & 4.75 & 4.82 & 4.41 & 0.34 \\
Ileum & 5.97 & 5.92 & 6.16 & 6.09 & 0.25 \\
Caeca & 6.41 & 6.39 & 6.62 & 6.47 & 0.32 \\
Cloaca & 6.18 & 6.09 & 6.28 & 6.4 & 0.29 \\
\hline
\end{tabular}

all differences in the rows were not significant

abbreviations see Table 2

The lactic acid bacteria and mannan oligosacharide with or without fumaric acid, administered to chickens, increased $(\mathrm{P} \leq 0.01)$ the counts of Streptococcus and Lactobacillus bacteria in the ileum. The counts of Streptococcus and Escherichia coli bacteria in the caecum decreased significantly $(\mathrm{P} \leq 0.01)$. No Salmonella, Shigella, Campylobacter or Clostridium were found in the small intestine or caecal digesta of any of the bird groups (Table 6). The Salmonella spp. and Shigella spp. in any sample of ileal digesta and Salmonella spp., Shigella spp. and Clostridium spp. in any sample of caecal digesta were not detected. 
Table 6. Viable counts of microflora in the ileal and fresh digesta of broilers, log cfu/g

\begin{tabular}{|c|c|c|c|c|c|}
\hline \multirow[b]{2}{*}{ Species of microflora } & \multicolumn{4}{|c|}{ Dietary treatment } & \multirow[b]{2}{*}{ SD } \\
\hline & control & antibiotics & $\begin{array}{l}\text { LAB } \\
\text { MOS }\end{array}$ & $\begin{array}{l}\text { LAB } \\
\text { MOS } \\
\text { FUA }\end{array}$ & \\
\hline \multicolumn{6}{|l|}{ Ileal digesta } \\
\hline Enterococcus & $4.40^{\mathrm{bB}}$ & $2.35^{\mathrm{aA}}$ & $4.51^{\mathrm{bB}}$ & $4.62^{\mathrm{bB}}$ & 3.11 \\
\hline Streptococcus & $1.58^{\mathrm{aA}}$ & $2.50^{\mathrm{bB}}$ & $2.50^{\mathrm{bB}}$ & $4.53^{\mathrm{cC}}$ & 1.62 \\
\hline Lactobacillus & $7.89^{\mathrm{a}}$ & $7.76^{\mathrm{a}}$ & $8.96^{\mathrm{b}}$ & $8.82^{\mathrm{b}}$ & 2.72 \\
\hline Escherichia coli & 4.52 & 5.50 & 5.08 & 5.12 & 2.80 \\
\hline Campylobacter & nd & 4.12 & nd & nd & 1.19 \\
\hline Clostridium & 2.59 & nd & nd & nd & 1.08 \\
\hline Bacillus & nd & 2.48 & 5.09 & 2.51 & 1.87 \\
\hline Proteus mirabilis & nd & nd & 2.52 & nd & 1.07 \\
\hline Enterobacter & nd & nd & nd & 2.49 & 0.96 \\
\hline Corynebacterium & 2.52 & nd & nd & nd & 1.01 \\
\hline \multicolumn{6}{|l|}{ Caecal digesta } \\
\hline Enterococcus & 3.52 & 3.38 & 3.00 & 3.56 & 1.33 \\
\hline Streptococcus & $8.38^{\mathrm{bB}}$ & $3.98^{\mathrm{aA}}$ & $4.05^{\mathrm{aA}}$ & $4.15^{\mathrm{aA}}$ & 3.18 \\
\hline Lactobacillus spp. & 7.50 & 7.30 & 8.82 & 8.90 & 2.18 \\
\hline Escherichia coli & $7.68^{\mathrm{cC}}$ & $7.26^{\mathrm{cC}}$ & $5.12^{\mathrm{bB}}$ & $3.33^{\mathrm{aA}}$ & 2.99 \\
\hline Campylobacter spp. & nd & 4.47 & nd & nd & 1.21 \\
\hline Bacillus spp. & nd & nd & 2.48 & 2.53 & 1.13 \\
\hline Citrobacter freudii & nd & 2.50 & nd & nd & 1.09 \\
\hline
\end{tabular}

\section{DISCUSSION}

The present results demonstrate the beneficial effect of the probiotic composed of Lactobacillus paracasei KKP 824, Lactobacillus rhamnosus KKP 825 and Lactobacillus rhamnosus KKP 826 on the growth and survival of broiler chickens, when used concurrently with MOS, with or without FUA. Also Simon et al. (2001) and Patterson and Burkholder (2003) reported positive effects of broiler diets supplemented with Lactobacillus, Bifidobacterium, Bacillus, Enterococcus and Streptococcus bacteria. The bacterial flora of the digestive tract is the first barrier that protects the host's organism against pathogen colonization. The beneficial effect of lactic acid bacteria on birds involves the colonization of the mucous membrane of different parts of the digestive tract, and protection of the mucous membrane against pathogenic bacteria. Lactic acid bacteria ferment glucose in the digestive tract of birds into lactic and acetic acids. It was found that some species of lactic acid bacteria (e.g., Enterococcus faecium) inhibit the growth 
of Salmonella pullorum, thus reducing the mortality of experimentally infected chickens (Audisio et al., 2000). It was also shown that Lactobacillus increase immunoresistance to infections with Eimeria acervulina (Dalloul et al., 2003). Another beneficial activity of lactic acid bacteria is the synthesis of bacteriocines (Joerger, 2003).

The strains of Lactobacillus paracasei and Lactobacillus rhamnosus used in this study had a favourable effect on feed intake and lowered chicken mortality. A beneficial effect was seen when the probiotic was provided in conjunction with the mannan oligosaccharide and fumaric acid. Oligo- and polysaccharides, known as prebiotics, are not digested in the digestive tract of chickens. It has been hypothesized that they are able to coat the mucous membrane with a thin protective layer that inhibits the adhesion of pathogenic bacteria (Gibson and Roberfroid, 1995). Mannan oligosaccharide (MOS) derived from yeast cell walls, used at a rate of $0.11 \%$ of the diet, significantly increased the body weight gains of turkeys to 8 weeks of age and feed conversion, compared with the unsupplemented group (Savage and Zakrzewska, 1996). It has also been shown that dietary MOS reduces the levels of Salmonella and bacterial spores in the intestines of broiler chickens (Spring et al., 2000). Savage and Zakrzewska (1996) suggest that MOS can increase the concentration of immunoglobulins in the intestines, which may limit the number of pathogens such as Clostridium perfringens.

Improvements in body weight, compared with the unsupplemented control group, were obtained in the present study by the use of lactic acid bacteria and mannan oligosaccharide with fumaric acid. Organic acids, including acetic, formic, propionic and fumaric acids are used as factors against colonization by moulds and Salmonella spp. (Berchieri and Barrow, 1996). Fumaric acid used in feeds for poultry and pigs reduced the buffering capacity and the $\mathrm{pH}$ of digesta in the terminal parts of the digestive tract, including the caecum and cloaca. However, this preventive action was not confirmed in our study.

The perspective of using short-chain organic acids as an antibacterial factor in poultry nutrition was discussed by Ricke (2003). The concurrent use of three experimental factors (lactic acid bacteria, mannan oligosaccharide and fumaric acid) in the present study produced results similar to the use of lactic acid bacteria and mannan oligosaccharide alone. Based on the obtained results it is difficult to reach a conclusion concerning the effect of fumaric acid on chickens. Significant differences were found in the weight of the liver, which significantly decreased in the experimental groups. Chicken fatness did not exceed the permissible standards and was similar to the values obtained by Brzóska et al. (1999) and Pesti et al. (2002).

A significantly lower $\mathrm{pH}$ of breast muscle was found in the chickens from the antibiotic group (ANT) compared with the controls (CON). Muscle pH is considered to be one of the most important physical parameters of meat quality 
and is widely used as an indicator of the technological and sensory quality of poultry meat (Fletcher, 1999). Muscle $\mathrm{pH}$ after slaughter decreases as a result of the biochemical process of tissue glycogen conversion into lactic acid. It is supposed that the glycolytic enzymes responsible for this process become deactivated once tissues reach a certain degree of acidity (Young et al., 2004). The results of the present study indicate that the type of antibacterial supplement used does not have a significant effect on the chemical composition of the breast muscle of broilers.

Microbiological analyses of the small intestine digesta showed that the probiotic increased the intestinal counts of Enterococcus, Streptococcus and Lactobacillus bacteria compared with the unsupplemented control group and with the antibiotic-supplemented group. In the caecum, the Streptococcus, Escherichia coli and Clostridium counts were considerably reduced. No Salmonella, Shigella, Campylobacter or Clostridium bacteria were found in the small intestine or in the caecum. These results conform with the results of earlier studies concerning the bacterial composition of the digestive tract of birds, including birds receiving probiotic bacteria (Barnes et al., 1972; Brzóska et al., 2005). The results confirmed that the probiotic containing Lactobacillus paracasei spp. paracasei KKP 824, Lactobacillus rhamnosus KKP 825 and Lactobacillus rhamnosus, used together with mannan oligosaccharide in the diet of birds, increased the population of Lactobacillus, Streptococcus and Enterococcus spp. bacteria in the small intestine and in the caecum, both in the unsupplemented control group and in the antibioticsupplemented group.

\section{CONCLUSIONS}

Mannan oligosacharide with lactic acid bacteria, with or without fumaric acid, was as effective in broiler diets as an antibiotic. These additives inhibit the count of Escherichia coli in the broiler digestive tract, reduce the chicken mortality and improve the dressing percentage in comparison with the antibiotic-containing diet. The investigated additives did not have adversely affect the breast or leg muscle yield, feed conversion, breast muscle $\mathrm{pH}$ or chemical composition of breast meat.

\section{ACKNOWLEDGEMENTS}

The author wishes to thank Premixes Company BASF Kutno for preparing the premixes and Barbara Brzóska, M.Sc. for selecting and caring for the chickens, taking samples of feed, meat and digesta and the supervision of broiler slaughter. Special thanks are extended to the employees of the Central Laboratory of the 
National Research Institute of Animal Production, Dr. Krystyna Sala, Marta Szczypuła M. Sc., and Zdzisław Czmer for performing the chemical analyses of feed, meat and statistical analyses of the data.

\section{REFERENCES}

AOAC, 1990. Official Methods of Analysis, Association of Official Analytical Chemists. 15 Edition. Arlington, VA

Audisio C.M., Oliver G., Apella M.C., 2000. Protective effect of Enteroccocus faecium J96, a potential probiotic strain, on chicken infected with Salmonella pullorum. J. Food Protect. 10, $1333-1337$

Barnes E.M., Mead G.C., Barnum D.A., 1972. The intestinal flora of the chicken in the period 2 to 6 weeks of age, with particular reference to the anaerobic bacteria. Brit. Poultry Sci. 13, 311-326

Berchieri Jr. A., Barrow P.A., 1996. Reduction in incidence of experimental fowl typhoid by incorporation of a commercial formic acid preparation (Bio-AddTM) into poultry feed. Poultry Sci. 75, 339-341

Brzóska F., Buluchevskij S.B., Śliwiński B., Stecka K., 2005. Preliminary study of the microbial spectrum of the digestive tract in broilers fed diets with and without antibiotic supplementation. J. Anim. Feed Sci. 14, Suppl. 1, 431-434

Brzóska F., Grzybowski R., Stecka K., Pieszka M., 1999. Effect of probiotic microorganism vs. antibiotics on chicken broiler body weight, carcass yield and carcass quality. Ann. Anim. Sci. 26, 303-315

Cavazzoni V., Adami A., Castrovilli C., 1998. Performance of broiler chicken supplemented with Bacillus coagulans as probiotic. Brit. Poultry Sci. 39, 526-529

Chaveerach P., Keuzenkamp D.A., Lipman L.J.A., Van Knapen F., 2004. Effect of organic acid in drinking water for young broilers on campylobacter infection, volatile fatty acid production, gut microflora and histological changes. Poultry Sci. 83, 330-334

Dalloul R.A., Lillahoj H.S., Shellem T.A., Doerr J.A., 2003. Enhanced mucosal immunity against Eimeria acervulina in broilers fed a Lactobacillus-based probiotic. Poultry Sci. 82, 62-66

Fletcher D.L., 1999. Broiler meat color variation, $\mathrm{pH}$ and texture. Poultry Sci. 78, 1323-1327

Gibson R.G., Roberfroid M.B., 1995. Dietary modulation of the human colonic microbiota: Introducing the concept of prebiotics. J. Nutr. 125, 1401-1412

Jin L.Z., Ho Y.W., Ali A.M., Abdullah N., Ong K.B., Jalaludin S., 1996. Adhesion of Lactobacillus isolates to intestinal epithelial cells of chicken. Lett. Appl. Microbiol. 22, 229-232

Joerger R.D., 2003. Alternatives to antibiotics: bacteriocins, antimicrobial peptides and bacteriophages. Poultry Sci. 82, 640-647

Patterson J.A., Burkholder K.M., 2003. Application of prebiotics and probiotics in poultry production. Poultry Sci. 82, 627-631

Pesti G.M., Bakalli R.I., Qiao M., Sterling K.G., 2002. A comparison of eight grades of fat as broiler ingredients. Poultry Sci. 81, 382-390

Ricke S.C., 2003. Perspectives on the use of organic acids and short chain fatty acids as antimicrobials. Poultry Sci. 82, 632-639

SAS, 1989. SAS/STAT User's Guide. Ver. 6. SAS Institute Inc., Cary, NC

Savage T.F., Zakrzewska E.I., 1996. The performance of male turkeys fed a starter diet containing a mannan oligosaccharide (Bio-Mos) from day old to eight weeks of age. In: T.P. Lyons, K.A. Jacques (Editors). Biotechnology in the Feed Industry. Proceedings of Alltech's 12th Annual Symposium. Nottingham University Press, Nottingham (UK), pp. 47-54 
Simon O., Jadamus A., Vahjen W., 2001. Probiotic feed additives effectiveness and expected modes of action. J. Anim. Feed Sci. 10, 51-67

Spring P., Wenk C., Dawson K.A., Newman K.E., 2000. The effects of dietary mannaoligosaccharides on cecal parameters and the concentrations of enteric bacteria in the ceca of salmonellachallenged broiler chicks. Poultry Sci. 79, 205-211

Van der Wielen P.W., Biesterveld S., Notermans S., Hofstra H., Urlings B.A., Van Knapen F., 2000. Role of volatile fatty acids in development of the cecal microflora in broiler chickens during growth. Appl. Environ. Microbiol. 66, 2536-2540

Young O.A., West J., Hart A.L., Van Otterdijk F.F.H., 2004. A method for early determination of meat ultimate pH. Meat Sci. 66, 493-498

Zgłobica A., Różycka B., 1972. Chicken Carcass Sloughtery Methods (in Polish). Ministry of Agriculture and Forestry (Editor). Warsaw, pp. 72-85

Zulkifli I., Abdullah N., Azrin M.N., Ho Y.W., 2000. Growth performance and immune response of two commercial broiler strains fed diets containing Lactobacillus culture and oxytetracycline under heat stress condition. Brit. Poultry Sci. 41, 593-597 